\title{
Increasing the Vote Number of the Albanian Political Parties Based on the Albanian Electorate Voting Behavior (Interested Stakeholders: Micro Level - Albanian Political Parties and Albanian Voter: Macro Level - Democracy Proficiency)
}

\section{Dorina Bërdufi}

PhD Candidate, University of Tirana E-mail: berdufidorina@gmail.com

\author{
Doi:10.5901/mjss.2013.v4n2p579
}

\begin{abstract}
Electorate voting behavior is one of the significant impact components on the socio-political and economic life of the Albanian Republic. This is officially formulated in the article 1, point 3 of the Albanian Constitute: 3 "Governance is based on a system of elections that are free, equal, general and periodic". It expresses the direct mechanism in which the individual takes part in political representation, constituting one of the directions in focus of the political parties whose aim is to increase the percentage of voters by offering programs during the electoral process in the interest of political platforms. This article analyses and advices how the parties should act to increase their voting percentage and become a "winner player of the electoral game". However, this is achieved only by bringing in stake the real interests of the voters, thus the development of policies based on their interests, based on of types of voting behavior, such as socio-economic, psychological, age, gender, individual and group interests, etc. As a result, the study and knowledge of the dynamics of voting behavior (absent, rational, ideological, neutral voting behavior) is the step that should take the "political party" actor for this purpose.
\end{abstract}

Keywords: Voting behavior; Albanian voter; political parties; Albanian context; increase vote percentage;

\section{Introduction}

The Albanian Republic is characterized from a lack of studies and analyzes of this type, expressed in the perception of misrepresented of the Albanian electorate from political parties; a problem that must get a solution which would be in the interest of both actors: primary actor "Albanian political parties" (through the increase of votes received) and secondary but no less important "Albanian electorate" actor (real representation of their interests in the political process). Given the fact that in June of this year (2013) will be held the parliamentary elections in the Republic of Albania, is an immediate need to analyze this problem and provide a solution, which in addition to meeting the micro level interests listed above, there will be positive also the completion of macro-level interests of the Albanian society as one of the elements of the country's democratic development.

The most important question of an electoral process is not for whom the voter voted but "how they voted," why and how they took this decision, based on which grounds? What are the implications of this decision? Why choose one party over another? And attached to the first concern is voting behavior: on which criteria this voter's choice was made (Jocelyn Evans 2004). In studies carried out for years, especially by Inglehart (consult Inglehart R. F. 2008, pg. 130 - 146) investigating the behavior of the electorate voting, from the viewpoint of dynamics, trends, and its incentive motives concrete manifestations encountered especially in developed Western countries, where the electorate's voting behavior is perceived more individuals with the right to vote as their active participation in the complex political decision-making. (A. Kocani, voting behavior studies, 2005-2012).

It is important to answer the above questions, as it is important to give the answer to questions such as "How political parties need to operate to increase the number of votes received by the voters of a country?", "What should be their attitude towards the electorate to achieve this goal?" Both of these processes are necessary for the improvement of the welfare and prosperity of the country as well as the one of meeting the interests of the actors involved in this analysis. The best way nowadays is to provide answers in the providing theoretical statistical studies and qualitative empirical form.

Voting is today considered as an "institution" of great importance to the development of democracy and the welfare of the country. Consequently, voting behavior is the component which should primarily be studied as such, analyzed in the context of political, economic, social, psychological, etc., Local and individual viewing of potential problems and giving 
best possible solutions, efficient and productive for the players involved. It is the act in which voters make their best choice. The question that will be answered below is "What are the selection criteria?" These criteria differ from individual to individual, but in political science theories, they can be grouped into several groups coming up in the forms of voting behavior. In this analysis I will attempt to provide key voting behavior patterns, characteristics of each approach attached to the Albanian context (as a former communist country and still transitional period of development of democracy).

\section{Main forms of voting behavior}

\subsection{Ideological voting behavior}

Identification with the ideology or party is the more stable indicator of a voting process, because it is a concept that represents the individual's relationship with the party through psychological identification with another group. This dimension of determining individual-group relationship is what we consider "identification" (Consult: Giddens, 2006). Voters have a psychological connection with their party and hardly change it with another one, labeled as "the psychosocial model" (Consult: Campbell, A., Converse, P. E., Miller, W. E. \& Stokes, D. E. (1960)) or otherwise known as the Michigan School. According to this theory "party identification is the biggest factor behind the voter's behavior" (Antunes R., 5 January 2013, pg. 146). This voting behavior plays an important role in the political process, in building policies, programs, group benefits, etc. The percentage of the electorate that has ideological behavior is devoted to his party and votes only that party, even if its policies may not have been entirely compatible with the program which this voter is loyal. In general, as far as increasing the age of the individual is more likely that the voters to stick loyal to his party voting ideologically. (A. Kocani, voting behavior studies, 2005-2012).

This behavior is a stable element but not completely unchanged in time. If an individual has attained a certain social position and status is less likely to change opinion in later years. If there is a change in party offer which make the individual feel abandoned by its traditional party, we can expect to see loss among older voters. However, in terms of individual differences, the expectation is that this loss can be reduced with age (Jocelyn A.J. Evans, 2004, pg. 192). One such case would be when the party acts for a long time against its ideology, then it is likely for the electorate to be disappointed by this party behavior and move to other groups of voting behavior such as absent behavior (A. Kocani, voting behavior studies, 2005-2012). The ideological voter needs a greater force to give up from his party identification in comparison to the other forms of voting behavior which are more flexible depending on the circumstances and interests of the actors involved. So, influential factors especially in the short time period lack in changing of this behavior. (consult: Berelson, Lazarsfeld, \& McPhee, 1954).

\subsection{Rational voting behavior}

The rational voting behavior of the Albanian electorate in years is increasing, due to this I will analyze this behavior and explain in the Albanian context longer than the other behaviors.

Voter chooses to vote for that party or candidate from which he/she will get the best benefit. It has to do with costeffectiveness concept and individual voters desire to maximize the benefit and pleasure attained as its candidate party for which he vote will win. This benefit of the voters will make the difference for whom to vote and whom not. Otherwise it can be considered as a rational choice. This theory suggests that the individual understands what he will get based on the criteria that he decides to make this choice. So, parties offer policies and voters decide which political alternatives are closer to maximizing their utility. Down in his model hypothesis says: parties formulate policies to win elections rather than win elections to formulate policies (Downs, A.., 1957, pg. 28). This thesis consists in: parties in democratic politics are analogues of entrepreneurs in a demanding economy benefit. So to achieve their desired conclusions they formulate any policy that believe they can win more votes, as any entrepreneur produces product that you think will bring more benefits (Downs, A., 1957, pg. 295-296).

So, the rational behavior is compared with the behavior of consumers and providers in a competitive market. A number of political parties and candidates present their products (politic programs for governance) and the voters choose between them by "paying" with the "vote" to the party that offers the product that best meets their criteria (Jocelyn A.J. Evans, 2004, pg. 72-72). Given the fact that the political party demand the vote and have the desire to maximize their votes in such a way to ensure victory and have secure bases to govern the country as well as being the winner in the next election. The same is the desire of the opposition. So the problem is how to collect and increase their voters support. "In this case, if we talk about the party with rational behavior, the concern would be about the social benefits that will undertake this government's rational or rational party. In this case the resulting social good (not the main intention of the 
parties) meet the desires of their voters. So, parties to maximize their benefit tend to maximize the benefit of the voters (Norris P., 2004). However, it should be mentioned at this point that not all individual desires can be fulfilled by party politics, so that the parties themselves are forced to return to running the completion of the greater benefit of the group, leaving un fulfilled especially groups small benefit (or small numbers groups), because the basic reason of this parties action is to increase the number of votes, in which the chances to meet the desiderate goals are greater in the first group of the majority.

The decision the voter takes in election time is based precisely on the benefit that he will take. The voter puts on scale the utility that brings the government in power with the benefit that can be obtained from the opposition and then takes the decision that balance inclines more, on the basis of greater benefit that can be obtained. Interesting in this case is an element: ceteris paribus, in the event that there is no difference between their benefit, voter abstains, because the choice was not based on "party supporting" and voting is not an act of "cost-free" (Jocelyn A.J. Evans, 2004, pg. 73). So there will be no reason to go to vote. The analogy to the market economy policy is such that there should be some conditions like "market competition". There should be freedom of entry into the market of providers, in these case "political party" which are trying to sell their product, in these case "vote" to the customer "the voter", which in turn makes a comparison between different products "vote" offered in the market and makes his choice based on the desire to maximize its benefit. In the same way the parties seek to maximize sales through increasing the number of votes sold. Presuming that there is a range of preferences among voters, parties will never be able to get all the votes, but as a competitive party will try to put themselves in acquiring more parts of the electorate. They make their appearance as widest as possible without losing credibility with contradictory policies which are designated to make these, whatever their preference structure (Jocelyn A.J. Evans, 2004, 77-78). So uncertainty and information for both parties and voters play an important role in the fact that any decisions will be rational. Politic market activity is not in terms of perfect and complete information. At the voter level, Downs makes a separation between different types of voters depending on the level of information and views of the parties (Downs, A., 1957, pg. 73). The more information the voter has and gets the surer will be his choice he makes, and vice versa. Although often, significant information costs time and fatigue to the rational voter, while in macro level this cost to the country's democracy, unlike ideological behavior which voter is identified with his party and psychologically feels an obligation to follow its political activity.

In the event that a large number of rational behavior voters will not vote, the reason is possibly from fatigue due to the electoral process. Voters feel that they are important (if many of them will abstain, then my vote, considering rational voters, will be more important). On the other hand, in the case of prior election polls, when presented possible rates of party's results, the rational voter will make the most efficient utility accounts obtained for the individual vote. The impression of voting for the party as per surveys is a potential winner would result in thinking to vote for the party which is more likely to win according to the results of the poll; higher benefits than to act otherwise. These can be considered as "stupid voters" (Schwartz, T., 1987, pg. 54:101-21 and I. Shapiro, 1994, pg. 55). Information can be easily manipulated and can be submitted incorrect information but based on the interests of different parties, a highly beneficial alternative organization for political parties to increase the number of votes received and gain government. However, this option remains to be used by political parties in recent weeks and days before the elections, so that in addition to this option it is necessary to find the solution of other options, which will be presented below.

\subsection{Apathetic voting behavior}

"Apathetic voting behavior refers to individuals who are bored, beat by the normal process of society and politics. They lack of desire for political activism, lack of motivation, lack of which may arise as a result of lack of money (the economic aspect), social skills, education, etc. As result of not having any interest in the politics, they pay no attention at it, activation or problems that it may include" (Woshinsky Oliver H., 2008, pg.107). The problem whose solution should be given is "this group of individuals needs to become active and take part in active voting of a country." The answer would be the solution to their problems, some of which is mentioned in the above analysis.

In any case, we are dealing with a percentage of a country's electorate. At a first glance this apathetic group could be considered unnecessary to bother demanding to make them active and transcend in other forms of voting behavior, because it is very difficult for an individual too tired and upset, which has lost interest and confidence in political process, to do so. It would be needed a much greater strength and gains or a greater benefit than the absentee behavior individual than analyzed above. In the event that the options offered by the political parties and their programs arouse the interest of the apathetic behavior voting electorate and turning them to active voters (which generally turn to pragmatic behavior), can occur in some cases where the percentage of the reactive voters is enough to make an overturn in election winners. So, may be crucial in some cases and relevant to the interests of political parties in other cases. Especially where the 
grey area of the electorate (undecided on which is part of apathetic behavior) has a large percentage of the electorate and population changes will constitute the greatest potential impact on the political process.

\subsection{Absent voting behavior}

Among the problems associated with voting behavior and present many practical interest today is that of abstention, or nonparticipation in voting. This voting behavior has a component that expresses the removal of social actors from their right and duty to participate in the decision-making process. This component is called "absentee voting behavior" (Berelson, Lazarsfeld, \& Mcphee, 1954, p. 308). Absent behavior in terms of voting is a situation in which voters feel are removed from the political process by which they can be engaged or they don't feel they represents them (Lipset, S. M.,1959a, pg 227). When a voter wishes are not fulfilled from a political party, voters will change the vote (when another party meets voters' wishes) or abstain (in cases where other political party fails to fulfill his desire, or when voter lack on desire). "In other words, the absentee voting behavior can be seen in the light of the system that does not take into consideration the interests of the voters: they do not feel part of the political process which is distanced from them". In many cases it turned out that one of the ways of the electorate to express his displeasure to the political class in general, or to its specific action is non participation in voting.

But of course generally this message does not «transcript» all electorate absent voting behavior of a country at a particular time. It may happen that in whole or in his most such absentee behavior does not have to do (or have very little to do) with the expression of frustration of the electorate (more precisely, a part of it) from the operation of their country's political class (Berelson, Lazarsfeld, \& Mcphee, 1954, p. 308). "This group can call the system non-democratic, corrupted or ineffective by which they wish not to use the legitimacy to represent their vote, or reaching the extreme of not voting, delegitimizing in such way the system" (Jocelyn A.J. Evans, 2004, pg. 77). In the absent group of elector there are also apathetic voters, not interested in voting, having not passed in any of the above processes of a classic abstainer (analyses which has been made above).

The observation of the 2009 parliamentary elections and local elections in 2011 shows that absent voting behavior trend has been declining (Jocelyn A.J. Evans, 2004, pg. 161). Assuming so, the percentage of the former absent voters disabled has passed in the form of pragmatic voting behavior. With the most importance at this point is analyzing the reasons for this change and focus strongly to these reasons in such a way to increase the number of votes of the interested parties as result of the increased number of the electorate that will participate in elections and will return to active political process, action that is followed as a positive externality of increasing s the level of democracy in the country.

\section{Elements that should be considered mostly in increasing the number of votes for political parties in the Albanian electoral context (a more concrete extension of voting behavior analyses)}

Usually when we talk about values in a society we take into account a set of indicators or "benchmarks" that orient the individual on making his choice linked on how he thinks, behaves and acts. Such benchmarks are conceived from individuals primarily through the process of education that along with family occupies a central place, a process that aims the internalization transform of social norms value. These values are grouped by the researchers in two opposite systems: as materialist system, post materialist, traditional, contemporary, etc. (This does claim for example, Ronald Inglehart, one of the most famous studier of value profile studies, Consult: R. Inglehart, 2000). (See: Kocani, A. Values system studies. 2004-2012).

\section{Benchmarks of more influent factors on Albanian electorate's voting behavior}

\subsection{Value profile system of the Albanian electorate}

Our political values are associated with a value our system as an individual and society. A form of usage policy is to share these values with others. As a country's macro-level events as well as personal tragedies or investments may affect the decision of the voters (Darice Britt, 7 February 2013). Inglehart, in particular for the former socialist countries, which enters also Albania, gives a value to their profile model that "lack of values": society tends toward those things that has retail and feels lacking (Inglehart, R., 2000).

In studies conducted by the Department of Political Science, Faculty of Social Sciences, University of Tirana, it appears that may be considered acceptable as a general trend towards the strengthening of materialist profile of 
Albanians, although there are elements, few in number and weight, which speak for a slight trend in the opposite direction. As indicators deterioration Inglehartian "subjective well-being" constituted signs of growing concern about the possibility social explosions in the population (Inglehart, R., Wayne E. Baker, 2000, February19), (See: Kocani, A. Values system studies. 2004-2012). which can be translated differently in the desire to change policy alternatives and programs as the perception of the electorate welfare comes getting worse. Individuals thus become even more pragmatic (not good living conditions or other problems increased in recent years) do individuals seek to satisfy their desires of the moment (which is itself an element of materialist profile) as well as physical and economic uncertainty, which will analyze the scale below. So that alternatives should be offered this electorate should be more and more to increase the usefulness of the voters.

\subsection{Importance of voting age}

General hypothesis is: with the increasing of age, the more likely the individuals go to vote. This is because young people do not know much of the voting institution and because there are not so integrated into political society (Inglehart, R., Wayne E. Baker, 2000, February 19). Given that the developed world studies in our country young people are more likely to adapt to the changes (are more liberal in their values change) them through policies developed and implemented by the parties can integrate more numerous in terms of supporting different parties. All this depends on what offer these parties, how reliable will be for young people, as increase their usefulness, etc. So, important is the development of EU policies and attractive to youth, which in Albania constitutes a significant percentage of voters, and likely a number of such can change the results from the profit of one party to another to come winner.

Based on the data of the number of young people voters (18-35 years) in Albania in 2011 was 720692 or 32.44\% of the population (INSTAT, January 5,2013 ). This percentage is sufficiently large enough to make a difference in winning party in elections. So a major focus of political parties during the election campaign but also during the rest of the political process should definitely be the study of the interests of young people, their attraction to certain parties, so as to increase the number of votes won elections. In addition, it is also important to take into account the fact that young people are more easily manipulated than larger ages for the above reasons and others that will be mentioned below.

Another convenience for platforms of political parties is that young people today are an interest group focused on the wishes of their age, education and employment. These should be areas in which political parties have to offer policies that teenagers should certainly be seen as applying and their usefulness upward. Conducted studies young people today generally go towards a value system materialist (Inglehart, R., Wayne E. Baker, 2000), so pragmatic voting behavior is more prevalent in this group.

\subsection{Education}

Education is another important element in increasing the number of voters. The more education to get much more individuals will have knowledge of them and their importance in the political process. They will also see voting as a civic duty. This argument also fits the Albanian context. The number of individuals who are enrolled and continue the university is increasingly growing. According to Instat the number of students enrolled at universities in Albania in 2010 was 697752 (INSAT, January 5, 2013). The young age and the lack of their curricula information results in a small knowledge percentage received about the political process and vote. So this hypothesis fits the Albanian context, because the only thing left are the university age students who have the possibility of integration and information about the politics and also the option of better selecting whether to vote or not, and if they vote: which party will vote based on their interests or criteria that will decide to make their selection. As an example, it is worth mentioning the work of the current Government (Democratic Party) to increase the number of universities which may be linked to the increasing number of positive voters.

\subsection{Family vs. Singles persons}

Individual with families go to vote more than single individuals, because studies says that these group of electorate is more stable in the society than single persons (in Albania this is also linked with the older age of those who are married), just as in general in addition to social stabilization married persons are more likely to be more stable economically, due to age and their commitment to keeping the family (partners themselves, their children or even in the case of our country with some family home crowns). Being more stable in the society they are also more involved in the political process and become more followers of this process to meet their needs and desires. Just as they feel involved and members of 
political society in decision-making and policies for the development of the country, ranging from the individual level and passed in the interests of a group of individuals or society as a whole.

\subsection{Socioeconomic context and Income}

Socioeconomic context and income there are two hypotheses about the well-being of individuals, economic development and voting. The higher the welfare and economic development of a country (GDP, inflation, unemployment, etc.) If these works well, individuals are more integrated into society and thus will pay more attention to the political process and voting. In a stable economic society people are less interested in political issues (Lipset, S. M. 1959, pg 227).

But on the other hand there is also the assumption that if you pick a country's economic level, individuals are unemployed, welfare is at low levels, i.e., in an economic crisis, "individuals will have more time and want to spend time with politics than in their own socio-economic welfare. This is because they will want their say on the efforts that they come out of the crisis.

Table 1. Albanian country GDP \& Inflation in last four years

\begin{tabular}{|l|c|c|c|c|}
\hline Year & $\mathbf{2 0 0 8}$ & $\mathbf{2 0 0 9}$ & $\mathbf{2 0 1 0}$ & $\mathbf{2 0 1 1}$ \\
\hline GDP (World Bank, February, 5 2013) & 7.7 & 3.3 & 3.5 & 3.3 \\
\hline Inflation (World Bank, February, 5 2013) & 3.4 & 2.3 & 3.6 & 3.5 \\
\hline
\end{tabular}

Table 2. Unemployment (Index Mundi, February 5, 2013)

\begin{tabular}{|c|c|c|c|c|c|c|c|c|c|c|c|c|}
\hline Year & 2000 & 2002 & 2003 & 2004 & 2005 & 2006 & 2007 & 2008 & 2009 & 2010 & 2011 & 2012 (INSTAT, February 5 2013) \\
\hline$\%$ & 16 & 17 & 17 & 15.8 & 14.8 & 14.3 & 13.8 & 12.5 & 12.8 & 13.5 & 13.3 & 13.26 \\
\hline
\end{tabular}

- Persons over the age of 15 years according to the 2011 Population Census is: 2221572 (INSTAT, February 5, 2012)

- Unemployment among young people aged 15-24 years is 35.5\% (Index Mundi, February 5, 2012)

Empirical studies show a strong link between economic development and voting behavior in the former communist countries. As Albania is still considered in transition phase as former communist country, a number of reforms have been applied, which consequently brought about losing and winning their application on the basis of benefits and costs. These results have been highly influential in shaping elements of individuals voting behavior and making elections. Voters in these countries support those parties of which they expect to make policies favorable to them, rather than differences in history, culture, or the duration of the transition process (Fidrmuc Jan, 2000). It seems clear that in this respect the voters are mostly followers of pragmatic voting behavior, namely the requirement to maximize their usefulness

\section{Tips to increase the percentage of votes for political parties' concentration and building to electoral programs meet the interests of the voters:}

1. Due to the increase of the percentage of the rational voter, it is important for the parties to focus of building rational interest political programs

2. Focus on education and young voters, due to the increasing number of young people in Albania, young voters and their flexibility in voting. Building part of the programs in them interests

3. Focusing in the real and emerging problems of the Albanian electorate. Studies of the concern of the Albanian electorate state that economic problems (such as unemployment) are in the first range of problems to electorate to be solved.

4. Not to forget to form and implement platforms which electorate feel helps them sociological and psychological aspect of life.

5. By the interest and ideology of the party focusing in the single or the married persons (varying in the interests of the party and the more convenient way to decrease the number of vote and win) 


\section{Conclusions}

This article analyses the ways on how to increase the number of votes of the Albanian political parties based on knowing the voting behavior of Albanian electorate. The interested stakeholders are those of the micro level, the Albanian political parties and Albanian voter; and at macro level the democracy proficiency). As per presented analyses, there are a number of elements that should be considered mostly in increasing the number of votes for political parties in the Albanian electoral context connected to the voting behavior. In order to increase the number of voter, Albanian parties should focus their electoral program in solving the problems of the electorate and fulfilling as much as they can their interests. Problems emerging by studies are mostly related to the economic aspect. By analyzing the Albanian voting behavior it can be seen that, the number of the rational voting behavior is increasing (voter who vote by the interest of the moment or that want to maximize due utility form the vote). This utility differs in group ages, education, value profile, single or married people, etc. with the increasing of the age, education and being married, an individual of the electorate are more likely not to change their vote in years.

\section{References}

Arrows, K. (1986). Rationality of self and others in economic system. The Journal of Business, 59 (4), S385-S399.

Arrows, K. (1951). Social values and individual values. New York: John Willey \& Sons.

Bartolini, S. \& Mair, P. (1990). Identity, competition and electoral availability. New York: Cambridge University Press.

Blais, A. (2000). To vote or not to vote: the merits and limits of rational choice theory. Pittsburg: University of Pittsburg.

Berelson, B. R., Lazarsfeld, P. F. \& Mcphee, W. N. (1954). Voting: a study of opinion formation in a presidential campaign. Chicago: Chicago University Press.

Budge, I., Crewe, I. \& Farlie, D. (1976). Party identification and beyond. New York: John Wiley.

Campbell, A., Converse, P. E., Miller, W. E. \& Stokes, D. E. (1960). The american voter. New York: Willey.

Constitution of Albania 1998, http://www.cec.org.al/images/stories/eng/legjislacion/Albanian\%20Constitution.pdf

Curtice, J. (2002). The state of electoral studies: mid-life crisis or new youth? Electoral Studies (21), 161-168.

Dalton, R. J. (2000). The decline of party identifications. In D. J. Russell \& M. P. Wattenberg, Parties without partisans (pp. 19-36). New York: Oxford University Press.

Downs, A. (1957). An economic theory of democracy. New York: Harper Collins Publishers.

Fidrmuc Jan, Economics of Voting in Post-Communist Countries, Electoral Studies19 (2/3), Special issue: Economics and Elections, June/Sept. 2000

Giddens Anthony, Simos Griffiths, Sociology, Polity Press: Cambridge, 2006

Green, D. and I. Shapiro (1994) Pathologies of Rational Choice Theory, New Haven: Yale University Press.

Inglehart, R., Wayne E. Baker, Modernization, cultural change and the persistence of traditional values, American Sociological Review, 2000, Vol. 65 (February:19-51)

Inglehart, R., Wayne E. Baker, Modernization, Cultural Change, and the Persistence of Traditional Values, American Sociological Review, 2000, Vol.65 (February).

Inglehart, R. F. Changing Values among Western Publics from 1970 to 2006, West European Politics, Vol. 31, Nos. 1-2, 130 - 146, January-March 2008

Inglehart, R., «Globalization and Postmodern Values», Washington Quarterly, 23.1 (2000).

Inglehart, R., Modernization and Postmodernization: Cultural, Economic and Political Change in 43 Societies. Princeton: Princeton University Press, 1997.

Inglehart, R., The Silent Revolution: Changing Values and Political Styles among Western Publics (Princeton: Princeton University Press, 1977)

Jocelyn A.J. Evans, Voters and voting, SAGE Publications Ltd London, 2004,

See: Kocani, A. Voting behavior studies. 2005-2012 (Data presented in conferences and scientific journals, as also in political science student's diploma's thesis, supervised from A. Kocani)

See: Kocani, A. Values system studies. 2004-2012 (Data presented in conferences and chientific journals, as also in political science student's diploma's thesis, supervised from A. Kocani)

Kocani, A.,,Pse na mungojnë sondazhet? - Vizion Plus - News - Lajme, http://www.youtube.com/watch?v=EKYsP12TyLE

Kiewiet, R. (1983). Macroeconomics and micropolitics: the electoral effects of economic issues. Chicago: University of Chicago Press.

Lipset, S. M. (1960). Political man: the social bases of politics. New York: Doubleday \& Company.

Lipset, S. \& Rokkan, S. (1967). Cleavagen structures, party systems, and voter alignments: an introduction. In S.

Lipset \& S. Rokkan, Party systems and voter alignments: cross national perspectives (pp. 1-64). New York: Free Press.

Norris, P., Electoral Engineering, Voting Rules and Political Behavior, Cambridge University Press, New York, 2004

Rossi, P. H. (1964). Four landmarks in voting behavior. In F. Munger \& D. Price, Readings in political parties and pressure groups (pp. 304-347). New York: Thomas. Y. Crowell.

Sniderman, P. M., Brody, R. A. \& Tetlock, P. E. (1991). Reasoning and choice: explorations in political psychology. Cambridge: 
Cambridge University Press.

Schwartz, T. (1987) 'Your vote counts on account of the way it is counted', Public Choice, 54:101-21.

Turner, J. C., Hogg, M. A., Reicher, S. D. \& Wetherell, M. S. (1987). Rediscovering the social group: a self categorization theory. Oxford: Blackwell.

Woshinsky Oliver H., EXPLAINING POLITICS Culture, institutions, and political behavior, Routledge: New York, 2008

Antunes R., Theoretical models of voting behavior, http://www.exedrajournal.com/docs/N4/10C_RuiAntunes_pp_145-170.pdf

Darice Britt The Psychology Behind Voting Behavior. http://source.southuniversity.edu/the-psychology-behind-voting-behavior106983.aspx

Hasimja E., Sjelljet zgjedhore dhe racionaliteti i votuesit shqiptar, Gazeta Polis http://revistapolis.com/polis/index.php/polis-1-paqmipolitik-othermenu-38/21-sjelljet-zgjedhore-dhe-acionaliteti-i-votuesit-shqiptar

Public Policy Issue Orientations:

http://www.icpsr.umich.edu/icpsrweb/instructors/setups/notes/public-policy- orientations.jsp

http://www.bbc.co.uk/bitesize/higher/modern/uk_gov_politics/elect_vote/re vision/2/

http://www.s-cool.co.uk/a-level/sociology/voting/revise-it/voting-behaviour

Index Mundi, Albania Unemployment, youth ages 15-24,

http://www.indexmundi.com/albania/youth_ages_15-24_unemployment.html

Index Mundi, Unemployment rate (\%), http://www.indexmundi.com/g/g.aspx?c=al\&v=74

Instituti i Statistikave, Shkalla e papunësisë së regjistruar T4 - 2012, http://www.instat.gov.al/al/figures/statistikakryesore.aspx,

INSAT, Studentë të regjistruar për çdo Universitet, sipas gjinisë

http://www.instat.gov.al/al/themes/arsimi.aspx?tab=tabs-5

INSTAT 2012, Censusi i Popullsisë dhe Banesave 2011

http://www.instat.gov.al/media/178070/rezultatet_kryesore_t_censusit_t_popullsis_dhe_banesave_2011_n_shqip_ri.pdf

The World Bank, Inflation, consumer prices (annual \%), http://data.worldbank.org/indicator/FP.CPI.TOTL.ZG World Bank, GDP (current US\$) , http://data.worldbank.org/indicator/NY.GDP.MKTP.CD 